\title{
The Application of Business Network Approach for Small and Medium Enterprises (SME) with regard to their Buying Behavior
}

- Škarpová Ludmila, Grosová Stanislava

\begin{abstract}
This paper presents a research study on Business Network (BN) approach within Small and Medium Enterprises (SME) based on the customer's buying behaviour. We believe that the interconnection of $\mathrm{BN}, \mathrm{SME}$ and buying behaviour is not sufficiently explored and there is a need for further studies in this respect. The main focus of this study is the explanation of customer's buying behaviour in Business to Business market (B2B) which is motivated by customer's effort to find a solution to his/her problems of rationalization or development. One of the major existing problems for SME is lack of resources (financial, human, technological) needed for the implementation of customer requirements (customer purchase). Lack of resources can be used from company's Business Network of suppliers and customers. Therefore, not only it is necessary for SME to know their BN and develop relationships with their own suppliers and customers, but also with suppliers of their customers. Using BN approach has resulted in creating strong relationships in $\mathrm{BN}$, thus building a stronger network and gaining a competitive advantage for $\mathrm{SME}$. The BN approach was applied in the market of manufacturing plastics companies which face great competition from SME in Zlín region.
\end{abstract}

Keywords: Business Network (BN), buying behaviour, small and medium enterprises (SME), resources JEL Classification: $M 29$

\section{INTRODUCTION}

Small and medium enterprises (SME) have the advantage of being flexible in reaction to fluctuating demand. They have big potential for technological and organisational innovation and change. SME have potential to generate jobs and income at the time when large firms have a rapid decline (Hashi \& Krasniqi, 2011).

SME have limited resources when compared with large firms. They have fewer financial resources and qualified employees (Storey \& Greene, 2010; Kowalkowski et al., 2013). A number of studies have established that SMEs can innovate and achieve efficient growth of their businesses only through creating and maintaining a network of partners (Westerlund \& Svahn, 2008; Cantù et al., 2010; Naudé et al., 2014). Networks are important especially to SMEs with limited resources as they are dependent on the others firms' resources (Gilmore et al., 2001; Mäläskä et al., 2011). Networking seems to have a positive impact on growth, it is a source of benefits (Hashi \& Krasniqi, 2011). The network is a special type of organizational form, which exists above the level of individual companies (Håkansson \& Ford, 2002). 
Networks are strategic for development and expansion of new ideas and innovations. Innovations are the key for creation of competitive advantage. Networks provide access to resources, knowledge and skills required for the development and exploitation of new business opportunities. Business innovation and competitive advantages don't arise in isolation from other companies (Freytag \& Young, 2014; LaPlaca, 2014). The success of the relationship, but also the result of a relationship, fundamentally depend on how well the two parties exploit resources owned by other companies (Forsström, 2005). The benefit of business network is that any positive effect (e.g. innovation and improvement) may be distributed among all participants, in direct and in indirect relationships. The truth is that strong players in the network are those who have made investments in the past and have the ability to mobilize their own resources and the resources of others. Those players have the final word on the network. The network does not provide equal opportunities to all who are associated with it, it supports mostly those who have major investments. It is due to the different abilities of the actors in the companies in the network (Håkansson et al., 2009).

SMEs are an important group in the market. The business network approach allows to: (a) Exploit the potential of the network to solve problems of strategic customers, (b) establish longterm relationships with them, and (c) gain a competitive advantage. SMEs cannot use business network approach for all of their customers due to prohibitive coordination costs. Therefore, it is important to choose appropriate customers.

In theoretical part, we seek answers to the following questions: (Q1) Does BN approach provide a solution for the lack of resources for SMEs? (Q2) Is the aim of buying in B2B market seeking solutions for customer's problems? (Q3) Is the creating relationships in BN an important part of buying in B2B market? In empirical part, we seek answer to the following question: (Q4) Is the $\mathrm{BN}$ approach as a useful tool how to increase the competitiveness?

\section{THEORETICAL BACKGROUND}

\subsection{Importance of SME}

SMEs are important sectors of developed market economies (Hallberg, 2000; Veber \& Srpová, 2008). They ensure uniform employment and more varied offering, provide a better choice for customers and increase negotiation power of customers against large enterprises.

Nožička (2012) has stated that against strong chains and large corporations are standing enterprises with fewer than 250 employees, which are known as small and medium enterprises. They are irreplaceable to satisfy local and small markets, to create jobs, to enhance offerings but also to open new markets based on the ability to flexibly utilize new ideas and technologies. According to Cooney and O'Connor (1996), smaller enterprises allow their size to move in closer contact with the market and to react flexibly to customers' requirements.

Technological innovation is an important element in today's economy. It is about extension of computers, internet, trend towards miniaturization, boom of biochemistry, nanotechnology and the use of electronic components in the automotive industry (Mohr, 2001). Technological innovations are important resources of competitive advantage for companies, for the whole industry 
and also for the society (Butje, 2005). SMEs play an important role in the technological innovation, especially in the early stages of the life cycle of technology. Since the Second World War more than $50 \%$ of innovations and even up to $95 \%$ of radical innovations have been created by SMEs. Some studies indicate that the process of continuous improvement in production can increase productivity and production flexibility and product improvement may lead to an increase in sales (Tidd et al., 2007).

\subsection{Problems of SME}

Lack of resources is a grave problem for SMEs. In connection with lack of availability of information there can be a limited perspective on market orientation, competition and trends in the wider market environment. These problems cause great mortality for SMEs (Havlíček \& Kašík, 2005). Lack of resources limits the possibilities for SMEs to invest in new equipment and, hence, they often depend on the different actors in the network which have the right resources (Ulaga et al., 2002; Kowalkowski et al., 2013). The key to success is the ability to coordinate the work with limited resources (Kowalkowski et al., 2013). From the environment outside the company, different resources can be obtained. The potential of a company will depend on its ability to combine these resources with its internal resources. Environment is constantly changing, and adapting the company to these changes is necessary (Håkansson \& Snehota, 2006). The limited resources of SMEs need to be complemented by external resources (Pressey et al., 2009). Due to networking capabilities of suppliers, SMEs get access to valuable resources (Ellegaard, 2006; Pressey et al., 2009).

SMEs (Cooney \& O'Connor, 1996) do not have the economic power to enable them to rapidly introduce new products to the market. Due to their size, they cannot benefit from economies of scale. Ford et al. (2006) say that SMEs have a lack of time to ensure that they can carry out their business. Nožička (2012) further highlights the need for customer information, competition and other members around the company to maintain a competitive advantage. SMEs do not have sophisticated information systems tailored to their needs.

Models and policy networks were inspired both by economic theory as well as innovative systems and clusters (Håkansson et al., 2009). Each firm must find and maintain long-term competitive advantage in the market (Blažková, 2007). BN approach allows for solving the customer's problem and also for using resources in the network. It is suitable for SMEs, which face great competition and are looking for a way to survive in the market and consolidate their position.

\subsection{Buying of SMEs and Business Network Approach}

SMEs would benefit from effective purchasing (Dollinger and Kolchin, 1986; Gadde \& Håkansson, 2001; Pressey et al., 2009). SMEs buy differently than large firms. They do not have time for long shopping. They require direct contact with one representative supplier, they use information on the internet and provide support after the sale. They want to build relationships and look for business partners. Sales strategy must be adapted to everyday problems of small businesses (Feder, J. B., 2003; Green, J., 2003; Kopytoff, 2003; Gilbert, J., 2004; Kotler, P. \& Keller, K.L., 2007). 
Ford et al., (2006) state: "Business purchases are driven by specific problems. Customers are seeking solutions to their problems. Solutions require an offering from a supplier. Offerings consist of a combination of: products/services/advice and delivery at a particular cost that will include but not be limited to the price paid. The solution to customer problems may also require adaptation by the supplier and effort and adaptation by the customer".

Purchasing departments in companies are becoming more important in development problems. Offering is the result of the relationship and interaction between supplier and customer. Solving most of the problems takes place due to the existing relations between the supplier and the customer. The main task of business marketing (and purchase) is: finding, developing and managing critical and important business relationships within a complex network that surrounds them (Ford et al, 2006). Purchase plays a major role in the managing of external resources and activities and their integration into relationships with other companies in the network (Håkansson et al., 2009).

A business network consists of many companies, each with their own problems and resources. Companies are linked together in order to solve those problems and to exploit those resources (Ford et al, 2006). Connection between BN and business relationships can be described as follows: Business network is a set of interconnected business relationships (Anderson et al., 1994). Each of a company's relationships is an important part of a wider portfolio of relationships. Ford suggested that managing of relationships portfolio is like managing of various stocks, as the aim is to maximize the return on investment in relationship. There must be sufficient resources and investment relationship with both the supplier and the customer. All the relationships define the company's position in the network (Ford et al., 2006). Opportunity for a new business can be developed through interaction and collectively discovered and exploited (Ciabuschi et al., 2012). Business relationships are interconnected and interacted with each other. Development of the relationship between the two companies is influenced by many factors: Past relationship, present relationship, experience of both companies from their other relationships, current events in other relationships of both companies, mutual expectations with respect to future events but also the wider network around two companies (that are not directly involved). Network paradox is that the existing relationships (and position in the network) restrict the company's ability to negotiate with new counterparts in the network. The only option for achieving change is through a network (Håkansson \& Ford, 2002).

Relationships are the basis for cooperation, the means to gain access to the resources of our suppliers, customers, other members of the network and resources in the wider area network (other networks). Managing of relationship is a long-term issue because it involved adapting offerings by both supplier and customer (Ford et al., 2006). The success factors for managing of relationships (Ulaga et al., 2002) are as follows: early access to new projects of customers and available knowledge for it; fast response to inquiries of customers; providing solutions to the customer's needs and delivering on promise; developing a relationship; handling projects from the beginning to the end; knowledge of potential customers and their actors; experience of staff and outside specialists for handling project.

The relationship evolves over time. At the beginning of the relationship, it requires knowledge of both parties and the direction in which these companies develop. During the existence of the 
relationship the necessary adaptation and commitments must be made by both parties (customer and supplier). Once a relationship has already existed, supplier can begin to focus on a detailed analysis of the customer (Freytag \& Clarke, 2001). Commitment and trust motivate marketers to maintain a relationship and investment in long-term cooperation with external partners. The presence of commitment and trust encourages skills, productivity and efficiency (Morgan \& Hunt, 1994). The relationship evolves because the customer believes that supplier will help solve one or more specific problems. Interactions between companies allow both an economic advantage from the outside world. Surrounding the company is a resource of potential cooperation and mutual benefit. Ongoing mutual interaction provides stability in a world that is unpredictable Håkansson et al., 2009).

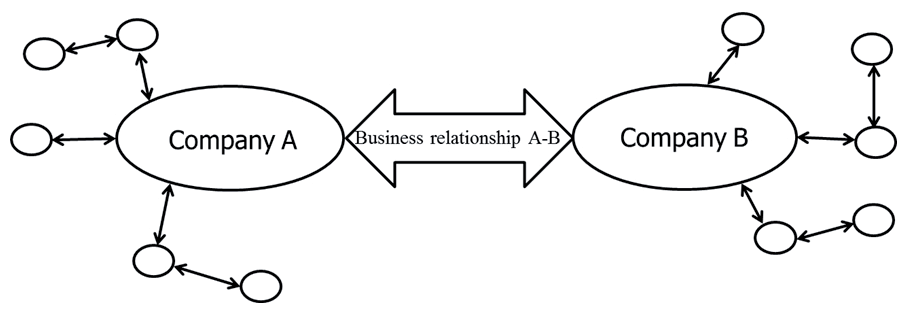

Fig. 1 - Connection of business relationships: complex questions. Source: (Håkansson et al., 2009), p. 249

\subsection{Customers in Business Network}

Ford et al. (2006) has stated the network approach as most appropriate in relation to the customer. The aim is to create an individual offering that will solve the specific customer's problem. Marketing in the B2B market is long-term activity and includes cooperation with the customer, but also with our suppliers and sometimes even with our competitors to solve the customer's problems and ours. It is necessary to understand the customer's environment and the networks of other companies within which business takes place, to know the problems and resources in the network. Freytag and Clarke (2001) have mentioned the existence of approaches that characterize the extent of the relationship between supplier and customer. On the one hand, we are talking about a simple market transaction without the need to build relationships. Further, close cooperation, strong ties and highly customized product (adapting to the needs and deficiencies of customers), there is a complex relationship managment. At some point, the market has been replaced by the term relationship passes from customer satisfaction in the short term to long term. (Sheth \& Sharma, 1997; Freytag \& Clarke, 2001) emphasize the need for a shift from transaction-oriented marketing strategy to relationship-oriented strategy, in response to the growing turbulence in the market and pressures to improve performance.

A supplier usually has a limited number of important customers. This is because it focuses only on selected issues. Large investments are needed just to meet the requirements of a few customers and the supplier does not have more resources needed to maintain relationships with several customers (Ford et al., 2006). The company develops through their relationships, so it is important to have proper counterparts in the relationship (Håkansson \& Ford, 2002). It is impossible 
to have a close relationship with every customer. It is necessary to make a strategic decision: With whom we want to create a relationship, how close a relationship, when the relationship will arise, for what purpose and which concept we choose (Harmel \& Prahalad, 1990; Freytag \& Clarke, 2001).

By using financial indicators and cost analysis we can determine the effectiveness of a particular business. However, they are insufficient to determine whether it is effective in a network. The effectiveness of the company can achieve diversity and innovation in the network. Companies need to gain access to the valuable resources of other companies. Development and use of opportunities arising from the interaction with others lead to sustainable growth. Only profitable growth is sustainable. Unprofitable growth is also due to dependence on suppliers or customers. Efficiency is the basis for measuring the performance of companies in the B2B networks (Mouzas, 2006).

For managing the relationship with a customer, it is necessary to understand him/her and his/ her problems. Application of network approach means that we must analyze current and potential customer relationships and analyze technological resources of the supplier and the customer. The basis of the relationship is to find solutions for customer's problems, but at the same time, to maximalize the return on investments to relationship and technologies. For the managing and evalutation of relationships in the network, it is also necessary to determine the actual cost of adapting offerings including cost for customer service. Portfolio relationships cannot be evaluated only based on financial indicators, because non-financial indicators are also necessary. Expanding customer base is difficult because the portfolio consists of different customers with specific requirements and problems. Before the foundation of the relationship and continuously thereafter, marketers are doing research on potential important customers during their personal visit. Customer research must be systematic and must be based on an analysis of financial reports and statements of customers Based on the output, we prepare a detailed plan on how to approach the customer and the creating of offering (Ford et al., 2006).

\section{RESEARCH METHODOLOGY}

We have investigated company $\mathrm{P}$, operating in a plastic industry, which is characterized by strong competition. Company $\mathrm{P}$ is divided in two divisions. In Division one was used the $\mathrm{BN}$ approach in relation to its strategic customers. Divizion two stayed with the traditional approach and its customers are from the segment Pyrotechnologies, compared with the division one through the continuous fall in the profit and loss of sales volume.

We analyzed all 50 customers of company P. The analysis was conducted in two rounds. At first, we used the financial indicators for the chosen 12 customers, who create $80 \%$ of sales in Division one. In the second round according to the non-financial indicators, we got three strategic customers: Customer F, Customer K and Customer C. The next step was to characterize their problems and do an analysis of the resources needed to solve these problems. Followed by knowledge of their business network, the analysis was applied to all participants in BN and the functionality of links between individual members was explored. Next was the selection of extent of the network, which is designed by specific problems. We present the procedure and the characteristics of $\mathrm{BN}$ of strategic customers. 
For managing the business relationships between the supplier and its strategic customers, the following processes are necessary: Selection of strategic customers according to financial and non-financial indicators, characterisation of choosing strategic customers, specification of their problems and needs, and the idea of solutions for their problems. The next step is to classify customers into categories based on the relationships portfolio of the supplier and to evaluate the benefit of the selected customer relationships

Selected financial indicators for choosing strategic customers:

- New products.

- Sales.

- Margins.

- Return on investment.

- Expected value in the future.

Selected non-financial indicators for choosing strategic customers:

- Source of new technology useful for other customers or providing a distinct competitive advantage.

- Connection with other relationships, the possibility of resource utilization in the customer's network.

- Satisfaction and trust in the relationship.

- Intensity and duration of the relationship.

" Growth potential of the relationship (new projects).

- The importance of the relationship of a customer.

The result of the strategic choice of customers is their inclusion in the portfolio of relationships. Ford et al. (2006) states: This portfolio is created by different relationships. The relationships are following: Yesterday's profits, the old men, the "fall-guys", the cash cows, Minor relationships, Today's profits, Tomorrow's profits and New technical or commercial requirements.

In the portfolio of relationships are the cash cows, the customers with the largest sales volume, but their profitability are declining over time. Minor relationships are made up of all small customers (Ford et al., 2006). This group as well as Tomorrow's profits must be continually analyzed and their potential in the future evaluated. Ford et al. (2006) states: The old men are based on the long-term interaction between friends among customer and supplier. These relationships are expensive and have no future. The "fall-guys" plans simply exploit the supplier, but the relationship has no future.

\section{RESULTS}

Customer $\mathrm{K}$ is from automotive industry. Its problem is Ca project, which belongs to rationalization. For successful running of this project supplier $\mathrm{P}$ must cooperate with suppliers $\mathrm{O}$ and GF of customer $\mathrm{K}$ and manage relationships in $\mathrm{BN}$ of the customer. Customer $\mathrm{K}$ has no resources 
necessary for this project. But in the case of loss of project it risks losing its strategic customers. Figure 2 provides the functional relationships in the network of the customer built by supplier $\mathrm{P}$. It also shows the relationships that were not functional. Over the life of the project ( 9 months) the waste was decreased from $65 \%$ to $35 \%$. There was a stabilization of supply, creating a safety stock to ensure continuity of production for all network members. Between company P and customer $\mathrm{K}$ a stronger relationship was built and cooperation was extended by 3 new projects. Now this customer belongs to Today's profits category.

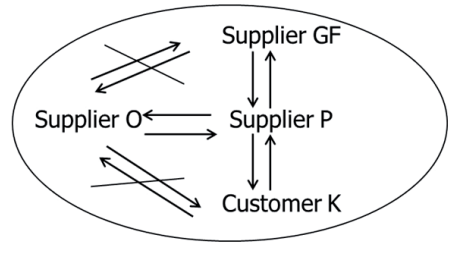

Fig. 2. - Customer K and its business network. Source: Authors.

Customer $\mathrm{C}$ is from construction industry. Its problem is the management of a wide range of products that are assembled together for its strategic customer $\mathrm{S}$. It also requires frequent innovations of existing products. Customer $\mathrm{C}$ is seeking solutions for the problems related to the rationalization and development. For successfull running of this project supplier $\mathrm{P}$ must cooperate with the customer $\mathrm{C}$ and with his customer $\mathrm{S}$. Supplier P must understand BN of customer $\mathrm{C}$ and participates in managing the relationships in $\mathrm{BN}$. Customer $\mathrm{C}$ does not have the manufacturing resources required to ensure the project. Figure 3 provides the functional relationships in the network of customers built by supplier P. It also shows the relationships that were not functional. During the existence of cooperation the number of new products increased up to 6 -times. Now this customer belongs to Today's profits category.

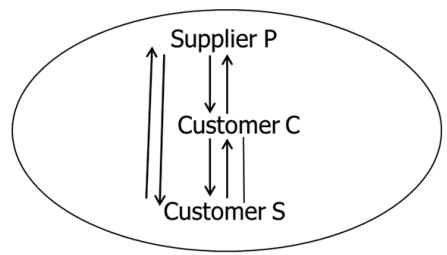

Fig. 3. - Customer C and its business network. Source: Authors.

Customer F operates in different industries, its customers are from Business to Customer market (B2C). Its problem is development and subsequent management of wide range of products that must meet high requirements of appearance. He also requires frequent innovation in product lines. Customer is seeking solutions for the problems related to the rationalization and development. For successful running of this project, supplier P must create a whole network of customer $\mathrm{F}$ and to manage cooperation between all members of the network. Customer F does not have the resources for implemetation of the project and cannot manage cooperation in network. Figure 4 provides the functional relationships in the network of customer built by supplier P. It also 
shows the relationships that were not functional. During the existence of cooperation the production portfolio increased by almost 100\%. Supplier P gained knowledge of new technology, which he used for other customers. Now this customer belongs to Today's profits category.

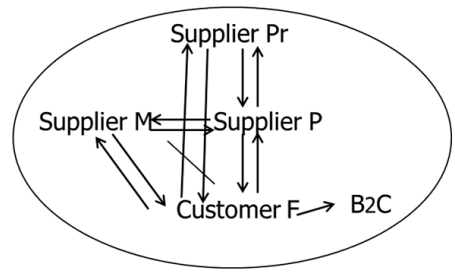

Fig. 4. - Customer F and its business network. Source: Authors.

Customer K, customer F and customer $\mathrm{C}$ were selected according to non-financial indicators. They all provide an important source of new technology for company P. Customer K enters successful to automotive industry, customer $\mathrm{C}$ experiences with assembly and customer $\mathrm{F}$ offers new technology. Company P gained access into customers' resources and network connection. As a result, Company P built the important relationship with its customer that was mutually adapted manufacturing operations and realized new projects.

The following tables provide sales of strategic customers compared with the total sales of Division 1 in company $\mathrm{P}$ and number of new products during the monitored period.

Tab. 1. - Sales of strategic customers for Division 1. Source: Authors.

\begin{tabular}{|l|c|c|c|c|c|c|}
\hline Sales mil. (CZK)/Year & 2009 & 2010 & 2011 & 2012 & 2013 & 2014 \\
\hline Customer K & - & - & - & 3,4 & 7,4 & 7,2 \\
\hline Customer C & 2,8 & 4,5 & 4,5 & 8,4 & 6,8 & 6,1 \\
\hline Customer F & - & - & - & - & 0,1 & 1,2 \\
\hline $\begin{array}{l}\text { Total amount of cus- } \\
\text { tomers }\end{array}$ & 2,8 & 4,5 & 4,5 & 11,8 & 14,2 & 14,5 \\
\hline Division 1 total & 15,0 & 17,3 & 20,2 & 24,2 & 26,7 & 29,0 \\
\hline
\end{tabular}

Tab. 2. - The number of new products related to strategic customers in Division 1. Source: Authors.

\begin{tabular}{|l|c|c|c|c|c|c|c|}
\hline $\begin{array}{l}\text { New products } \\
\text { number/Year }\end{array}$ & 2009 & 2010 & 2011 & 2012 & 2013 & 2014 & $2015^{*}$ \\
\hline Customer K & - & - & - & 1 & - & 1 & 3 \\
\hline Customer C & 4 & 3 & 2 & 29 & 6 & 11 & 6 \\
\hline Customer F & - & - & - & - & 11 & 9 & 9 \\
\hline Division 1 total & 4 & 3 & 2 & 30 & 17 & 21 & 18 \\
\hline
\end{tabular}

* Data are to 1.5.2015 
Tab. 3. - Comparison between Division 1 and Division 2. Source: Authors.

\begin{tabular}{|l|l|l|l|l|l|l|}
\hline Sales mil. (CZK) \Year & 2009 & 2010 & 2011 & 2012 & 2013 & 2014 \\
\hline Division 1 total & 15,0 & 17,3 & 20,2 & 24,2 & 26,7 & 29,0 \\
\hline Division 2 total & 19,3 & 25,2 & 23,9 & 21,1 & 15,3 & 12,8 \\
\hline
\end{tabular}

Table 3. provides a comparison of sales between Division one (BN approach) and Division two (traditional approach). In Division one, BN approach is applied based on solving problems and building relationships with strategic customers.

\section{MANAGERIAL IMPLICATIONS}

The purpose of this study is the application of $\mathrm{BN}$ approach to selected company $\mathrm{P}$ in the market of SMEs plastics companies in the Czech Republic in Zlín region. For five years, we have analyzed the selected indicators for company $\mathrm{P}$, its customers and suppliers. Due to the strong competition in the market among plastics companies, we were looking for ways to increase competitiveness. During the application of $\mathrm{BN}$ approach, company $\mathrm{P}$ has undergone many changes that have impacted positively its financial indicators of competitiveness.

If SMEs are facing big competition in the market, or is struggling with a decline in profits and losing customers, it's time to apply the BN approach. The findings of this study provide a structure for how to apply BN approach to SMEs in the market for production of plastic products. The first step is understanding the strategic customers and their BN. The next step is to find solutions to their problems using resources located on the network and building a relationship. By providing solutions to new problems, the customer can decide about remaining in the running projects. A new customer has great potential that we don't want to refuse, but we can use resources (knowledge and technology) from our suppliers for creating an offering, followed by building and maintaining the relationships of all involved counterparts in $\mathrm{BN}$ for the long run. The last step is the evalutation of the benefits of the relationships with customers, the analysis of the potential new and existing customers and their role in the portfolio of relationships. The risk of applying the BN approach is that a bad choice of customers, where we want to apply this approach. This would imply use of limited enterprise resources for unimportant customers.

\section{CONCLUSIONS}

We have observed that the application of $\mathrm{BN}$ approach had positive effect on the division one and this approach strengthened the company's position in the market and increased its competitiveness. In this paper, the scientific goal of presented methodology is applying the BN approach as a useful tool how to increase the competitiveness among SMEs. We believe that the application of $\mathrm{BN}$ approach in practice is the strategic key trend for future development of SMEs. In addition, clusters and ability of innovations play important roles in future development of SMEs.

$\mathrm{BN}$ approach is a new concept that still faces a lack of empirical studies. We have shown the possibility of its application in practice. Further investigation can be done to evaluate the benefits of bonds between strategic customers and applications of $\mathrm{BN}$ to other companies in the plastic 
industry. Next step of investigation will be examining changes in networks in the B2B market of selected companies, it means to analyze the dynamic of the networks. These topics are now the subject of on-going research investigation.

\section{References}

1. Anderson, C. J., Håkansson, H., \& Johanson, J. (1994). Dyadic Business Relationships Within a Business Network Context. Journal of Marketing, 58 (4), 1-15. http://dx.doi. org/10.2307/1251912

2. Blažková, M. (2007). Marketingové rízení a plánování pro malé a strédni firmy. Praha: Grada. ISBN 978-80-247-1535-3.

3. Butje, M. (2005). Product marketing for technology companies. Burlington, MA: Elsevier Butterworth-Heinemann.

4. Cantù, C., Montagnini, F., \& Sebastiani, R. (2010). Organizing a network within the network: The case of MC Elettrici. IMP Journal, 4 (3), 220-243.

5. Ciabuschi, F., Perna, A., \& Snehota, I. (2012). Assembling resources when forming a new business. Journal of Business Research, 65 (2), 220-229. http://dx.doi.org/10.1016/ j.jbusres.2010.11.029

6. Cooney, T. M., \& O'Connor, A. (1996). Perceived barriers to innovation in small to medium enterprises. Irish Marketing Review, 9, 87-97.

7. Dollinger, M. J., \& Kolchin, M. G. (1986). Purchasing and the small firm. American Journal of Small Business, 33-45.

8. Ellegaard, C. (2006). Small company purchasing: a research agenda. Journal of Purchasing and Supply Management, 12 (5), 272-283. http://dx.doi.org/10.1016/j.pursup.2006.08.004

9. Feder, J. B. (2003). When Goliath Comes Knocking on David's Door. New York Times, p. G13.

10. Ford D., Gadde, L.-E., Håkansson, H., \& Snehota, I. (2006). The Business Marketing Course, Managing in Complex Networks. England.

11. Forsström, B. (2005). Value co-creation in industrial buyer-seller Partnerships - creating and exploiting interdependencies: an empirical case study. Åbo: Åbo Akademi University Press.

12. Freytag, P. V., \& Clarke, A. H. (2001). Business to Business Market Segmentation. Industrial Marketing Management, 30 (6), 473-486. http://dx.doi.org/10.1016/S0019-8501(99)00103-0

13. Freytag, P., \& Young, L. (2014). Introduction to Special Issue on innovations and networks: Innovation of within, through and by networks. Industrial Marketing Management, 43 (3), 361364. http://dx.doi.org/10.1016/j.indmarman.2013.12.004

14. Gadde, L.-E., \& Håkansson, H. (2001). Supply Network Strategies. Chichester: Wiley.

15. Gilbert, J. (2004). Small But Mighty. Sales \& Marketing Management, pp. 30-35.

16. Gilmore, A., Carlson, D., \& Grant, K. (2001). SME marketing in practice. Marketing Intelligence \& Planning, 19 (1), 6-11. http://dx.doi.org/10.1108/02634500110363583 
17. Green, J. (21. April 2003). „Small Biz: Microsoft’s Next Big Thing?“ Business Week, pp. $72-73$.

18. Håkansson, H., \& Ford, D. (2002). How should companies interact in business networks? Journal of Business Research, 55 (2), 133-139. http://dx.doi.org/10.1016/S0148-2963(00)00148-X

19. Håkansson, H., Ford, D., Gadde, L.-E., Snehota, I., \& Waluszewski, A. (2009). Business in Networks. Chichester: John Wiley \&Sons.

20. Håkansson, H., \& Snehota, I. (2006). No business is an island: The network concept of business strategy. Scandinavian Journal of Management, 22 (3), 256-270. http://dx.doi. org/10.1016/j.scaman.2006.10.005

21. Hallberg, K. (2000). A Market-Oriented Strategy for Small and Medium Scale Enterprise. Washington, D.C.: The World Bank. http://dx.doi.org/10.1596/0-8213-4727-6 for ISBN 9780821347270).

22. Harmel, L., \& Prahalad, C.K. (1990). The Core Competence of the Corporation. Harvard Business Review Spring, pp. 79-91.

23. Hashi, I., \& Krasniqi, A.B. (2011). Entrepreneurship and SME growth: evidence from advanced and laggard transition economies. International Journal of Entrepreneurial Behavior \& Research, 17 (5), 456-487. http://dx.doi.org/10.1108/13552551111158817.

24. Havlíček, K., \& Kašík, M. (2005). Marketingové rízeni malých a strédních podnikü. Praha: Management Press.

25. Kopytoff, V. (28. July 2003). „Business Click on eBay“. San Francisco Chronicle, p. E1.

26. Kotler, P., \& Keller, K.L. (2007). Marketing management, Marketingová vsuvka: Návod jak. prodávat malým firmám. (Vol. 12), Praha.

27. Kowalkowski, Ch., Witell, L., \& Gustafsson, A. (2013). Any way goes: Identifying value constellations for service infusion in SMEs. Industrial Marketing Management, 42 (1), 18-30. http://dx.doi.org/10.1016/j.indmarman.2012.11.004

28. LaPlaca P. L. (2014). Letter from the Editor: Innovation in business networks. Industrial Marketing Management, 43 (3), 359-360. http://dx.doi.org/10.1016/j.indmarman.2014.03.001

29. Mäläskä, M., Saraniemi, S., \& Tähtinen, J. (2011). Network actors' participation in B2B SME branding. Industrial Marketing Management, 40 (7), 1144-1152. http://dx.doi.org/10.1016/ j.indmarman.2011.09.005

30. Mohr, J. (2001). Marketing of high-technology products and innovations. New Jersey: Prentice Hall.

31. Morgan, R. M., \& Hunt, S. D. (1994). The Commitment-Trust Theory of Relationship Marketing. Journal of Marketing, 58 (3), 20-38. http://dx.doi.org/10.2307/1252308

32. Mouzas, S. (2006). Efficiency versus effectiveness in business networks. Journal of Business Research, 59 (10-11), 1124-1132. http://dx.doi.org/10.1016/j.jbusres.2006.09.018

33. Naudé, P., Zaefarian, G., Tavani, Z. N., Neghabi, S., \& Zaefarian, R. (2014). The influence of network effects on SME performance. Industrial Marketing Management, 43 (4), 630-641. http://dx.doi.org/10.1016/j.indmarman.2014.02.004 
34. Nožička J. (2012). Tř̌ní orientace v malých a strednich podnicich s vysokým inovačním potenciálem (Doctoral dissertation). Praha.

35. Pressey, A., D., Winklhofer, H.,M., \& Tzokas, N., X. (2009). Purchasing practices in small -to medium-sized enterprises: An examination of strategic purchasing adoption, supplier evaluation and supplier capabilities. Journal of Purchasing and Supply Management, 15 (4), 214226. http://dx.doi.org/10.1016/j.pursup.2009.03.006

36. Sheth, J. N., \& Sharma, A. (1997). Supplier Relationships-Emerging Issues and Challenges. Industrial Marketing Management, 26 (2), 91-100. http://dx.doi.org/10.1016/S00198501(96)00153-8

37. Storey, D., \& Greene, F. (2010). Small business and entrepreneurship. UK: Financial Times/ Prentice Hall.

38. Tidd, J., Bessnt, J., \& Pavitt, K. (2007). Řizení inovací. Brno, Computer Press.

39. Ulaga, W., Sharma, A., \& Krishnan, R. (2002). Plant location and place marketing: understanding the process from the business customer's perspective. Industrial Marketing Management, 31 (5), 393-401. http://dx.doi.org/10.1016/S0019-8501(00)00151-6

40. Veber, J., \& Srpová, J. (2008). Podnikání malé a strední firmy. Praha, Grada.

41. Westerlund, M., \& Svahn, S. (2008). A relationship value perspective of social capital in networks of SMEs. Industrial Marketing Management, 37 (5), 492-501. http://dx.doi. $\operatorname{org} / 10.1016 /$ j.indmarman.2008.04.003

\section{Contact Information}

\section{Ing. Ludmila Škarpová}

University of Chemistry and Technology, Prague

Technické 5, 16628 Praba 6, Crech Republic

email:skarpova.ludmila@seznam.cz.

Doc. Ing. Stanislava Grosová, CSc.

University of Chemistry and Technology, Prague

Technická 5, 16628 Praha 6, Czech Republic

email:Stanislava.Grosova@vscht.cz. 